\title{
Phenotypic Characteristics of Exotic-Broiler, Kampung, Male Exotic- Layer, KUB-1 and Pelung Chickens
}

\author{
Saragih HTS ${ }^{1}$, Viniwidihastuti $\mathrm{F}^{2}$, Lembayu $\mathrm{RP}^{2}$, Kinanthi $\mathrm{AR}^{2}$, Kurnianto $\mathrm{H}^{3}$, Lesmana $\mathrm{I}^{1}$ \\ ${ }^{I}$ Staff Lecturer of Faculty of Biology, Universitas Gadjah Mada, Yogyakarta, 55281 \\ ${ }^{2}$ Student of Faculty of Biology, Universitas Gadjah Mada, Yogyakarta, 55281 \\ ${ }^{3}$ Central Java Assessment Institute for Agricultural Technology, IAARD, Ministry of Agriculture \\ E-mail: saragihendry@ugm.ac.id
}

(received 25-10-2018; revised 24-01-2019; accepted 24-01-2019)

\begin{abstract}
ABSTRAK
Saragih HTS, Viniwidihastuti F, Lembayu RP, Kinanthi AR, Kurnianto H, Lesmana I. 2019. Karakteristik fenotip ayam broiler eksotik, kampung, layer eksotik jantan, KUB-1 dan Pelung. JITV 24(1): 9-14. DOI: http://dx.doi.org/10.14334/jitv.v24i1.1889

Kebutuhan daging ayam selama ini didominasi oleh daging ayam yang berasal dari jenis ayam broiler eksotik (tetuanya eks impor). Potensi ayam pedaging lokal di Indonesia diharapkan mampu menyediakan ketersediaan kebutuhan daging ayam nasional. Tujuan dari penelitian ini adalah untuk mengetahui karakteristik fenotip day old chick (DOC) jenis-jenis ayam yang ada di Indonesia yang memiliki potensi sebagai ayam pedaging. Karakter fenotip yang dilihat berupa morfometri tubuh, berat organ viseral dan morfologi usus halus. Ayam yang digunakan merupakan DOC jenis ayam broiler eksotik, Kampung, Layer eksotik jantan, KUB-1 dan Pelung. Sebanyak 125 ekor yang terdiri dari 25 ekor setiap strain ayam pada umur posthatched diamati morfometri tubuhnya, berat organ viseral dan histo-morfologi usus halusnya. Data pengamatan kemudian dianalisa menggunakan analisis similaritas dengan menggunakan MVSP 3.22 untuk membuat dendogram dengan metode UPGMA (Unweighted Pair Group with Aritmetic Average). Hasil penelitian menunjukkan bahwa terdapat 2 klaster berbeda terhadap tingkat kesamaan dalam karakternya. Ayam broiler memiliki persentase similaritas 94,65\% terhadap Ayam layer jantan dan 92,26\% terhadap ayam pelung. Sementara ayam Kampung memiliki persentase similaritas 90,16\% terhadap Ayam KUB-1. Kesimpulan penelitian ini menunjukkan bahwa tingkat kesamaan karakter fenotip ayam pelung mendekati jenis ayam broiler dan jantan layer. Tingkat kesamaan ini diharapkan bahwa ayam pelung dapat sebagai jenis ayam lokal yang berpotensi sebagai ayam pedaging.
\end{abstract}

Kata Kunci: Day Old Chick, Morfometri, Organ

\section{ABSTRACT}

Saragih HTS, Viniwidihastuti F, Lembayu RP, Kinanthi AR, Kurnianto H, Lesmana I. 2019. Phenotypic characteristics of Exotic-broiler, Kampung, Male Exotic-layer, KUB-1 and Pelung chickens. JITV 24(1): 9-14. DOI: http://dx.doi.org/10.14334/jitv.v24i1.1889

The needs for chicken meat have been dominated by meat from exotic broilers (bred from imported parent). The potential of local broilers chicken in Indonesia is expected to be able to provide the meat for national needs for chicken meat. The objective of this research was to determine the day-old-chick (DOC) phenotypic characteristics of chickens in Indonesia that have the potential as broilers. The phenotypic characteristics are in the form of body morphometry, visceral organ weight and small intestinal histo-morphology. The chickens used were the DOC type of exotic Broiler, Kampung, exotic male Layer, KUB-1 and Pelung. A total of 125 chickens consisting of 25 chickens of each strain at posthatched age were observed for its body morphometry and its visceral organ weight, and small intestinal histo-morphology. The observed data were then analyzed by similarity analysis using MVSP 3.22 to create a dendogram with the Unweighted Pair Group with Aritmetic Average (UPGMA) method. Results showed that there were 2 different clusters from the level of similarity in their characteristics. Exotic broilers had $94.65 \%$ similarity to male exotic layer chicken and $92.26 \%$ to pelung chicken, while Kampung chickens had $90.16 \%$ similarity to KUB-1Chicken. In conclusion, it is indicated that the level of similarity of the phenotypic characteristics of pelung chickens were close to the type of exotic broiler and male exotic layer chicken. This level of similarity lead to the expectation that pelung chickens potential to be a candidate for meat-type of local chicken.

Key Words: Day Old Chick, Morphometry, Organs

\section{INTRODUCTION}

Food proteins source derived from animal such as beef, sheep, goat, and chicken meats are in great demand for Indonesian people. Protein needs through chicken meat have been mostly fulfilled by exotic broiler chickens. This dominance is very reasonable because the exotic broiler chicken grow faster, which is within 35 days they are ready to be harvested with an average live weight of $2 \mathrm{~kg}$ per chicken. Besides the fast growth, the availability of broiler chicken meat has also been supported by big modern broiler chicken companies. (Tamalludidi 2012).

The attempts to find alternative chicken meat availability apart from broiler chickens continue to be carried out by the Indonesian government and the 
society. Indonesian government through The Indonesian Research Institute for Animal Production (IRIAP) has been continuing research. to create innovations in meeting the demand of . local chicken DOC. Moreover the society has also been trying to increase local chicken meat by crossing male local chickens with exotic laying hens. The product are commonly called as Jawa Super chickens (Setiawan et al. 2018).

The pure local breed of chickens that have high potential of body weight is Pelung (Nataamijaya 2000). Pelung chicken, besides being known as ornamental chicken that has long crowing sounds, it also has a good growth ability to reach body weight of $1.1-1.3 \mathrm{~kg}$ in 3 months (Iskandar \& Susanti 2007).

Local chicken has the potential to become a national chicken meat industry because so far the society as consumers prefer local or kampung chicken meat. Kampung chicken meat more recognizable by Indonesian consumers as it is more delicious taste compared to exotic broiler chicken meat. However, the frequently-faced problems by local chicken producers was the low productivity of kampung chickens either in body growth of only optimally of $1.2-1.5 \mathrm{~kg} /$ chicken or egg weight which ranged between 30-40 grams (Nataamijaya 2010). Recently, there are improved broiler type of local chicken, called SenSi-1 Aagrinak (Iskandar 2018) and improved egg type of local chicken called KUB-1 chicken (Sartika et al. 2013). Both breeds were produced at the IRIAP and disseminated throughout the country through licencing system to private local chicken breeder companies (Iskandar 2018).

Knowledge of the phenotypic characteristics of the types of chicken in Indonesia is very important to see the potential of broilers in Indonesia. Therefore, research needs to be conducted since the age of DOC in order to get information from the beginning of the phenotypic characteristics of these types of chicken.

Therefore, this research was aimed to determine the phenotypic characteristics of several breeds of chickens in Indonesia which have the potential to become broiler type of chickens in order to meet the needs of the National chicken meat.

\section{MATERIALS AND METHODS}

The research was carried out in stages, which are the measurements of chicken morphometry, visceral organ and villus height, crypt depth and number of small intestine goblet cells (duodenum, jejunum and ileum). The entire research was conducted at the Laboratory of Animal Structure and Development of the Faculty of Biology, Gadjah Mada University.

In this research used 125 DOC were used, nconsisting of 25 chickens from each breed or strain. There were exotic (which was a modern breed derived from imported parent or grand parent) broiler, kampung, exotic male layer, Kampung KUB and Pelung chickens. The chicks of exotic broiler, kampung, pelung and exotic male layer chickens were obtained from chicken distributors in Yogyakarta area, while KUB-1 chickens were obtained from the farmer partners of IRIAP in Berbah, Tirtosari, and Yogyakarta regions. Observations of the phenotypic characteristics included the following steps:

\section{Measurement of chicken morphometric}

Morphometric measurement was performed on DOC of all 5 breeds of chickens. The measurement conducted refered to the chicken phenotypic characteristics using midline and ruler.

\section{Measurement of chickens visceral organ weight}

Measurement of visceral organ weight was performed on DOC of all 5 breeds of chicken. The measurement was carried out on 10 chicks from each breeds using semi-analytic scales. The measurements of chickens' visceral organ weight included the liver, heart, proventriculus, ventriculus, length of the small intestine, weight of the small intestine, weight of the bursa of fabricius, weight and area of $1 / 2$ part of the Pectoralis thoracicus muscle (PT).

\section{Preparation of small intestine histology slides}

Ten DOCs from each breed were sacrificed. The chickens were then dissected and duodenum, jejunum and ileum, were taken.The organs taken were then fixed in Bouin solution for approximately 12 hours. Afterwards, the organs were washed using $70 \%$ alcohol until the solution was not yellow.

After washing the organs were dehydrated. Dehydration of the small intestine was done using multilevel alcohol and then proceed with the process of clearing and infiltration. The embedding was performed using pure liquid paraffin. The next stage was trimming and sectioning which was followed by Hematoxylin \& Eosin (H\&E) and Periodic Acid Schiff's (PAS) staining.

The stages of measurement of villus height, crypt depth and number of small intestine goblet cells were carried out by finding the location of the villus and crypt, which was observed under a light microscope with a magnification of $4 \times 10$ and $10 \times 10$. The observation results were photographed using a Leica microscope, connected to a computer, and analyzed using raster image and J. Imagesoftware.

\section{Data analysis}

The measurement of research data used were semi analytic scales, midline scale, Leica microscopy, ImageJ program, Image Raster 3. The data obtained were quantitative data of chickens' morphometry, visceral organ weight, villus height and crypt depth, ratio of villus height/crypt depth, goblet cell area and number of goblet in $100 \mu \mathrm{m}$ villus height. The data 
were analyzed using SPSS 13.0 and the similarity analysis using MVSP 3.22 to create a dendogram with the UPGMA method (Unweighted Pair Group with Aritmetic Average).

\section{RESULTS AND DISCUSSION}

The characteristics of morphometry (Table 1), visceral organ (Table 2), and small intestine structure (Table 3 and Figure 1) on DOC of the 5 breeds observed, were analysed using UPGMA method (Unweighted Pair Group with Aritmetic Average), showing that there were 2 clusters of similarity level. UPGMA analysis result was in the form of dendogram that showed the similarity level of characteristics in the type of chicken used (Figure 2). The five types of chicken used in this research had a similarity level of $86.39 \%$. The first cluster, which was kampung and KUB-1 chickens, has the highest similarity level reaching $90.16 \%$. The second cluster consisted of Pelung, exotic male layer and exotic broiler chickens with a similarity level of $92.26 \%$. This second cluster formed two different clusters, Pelung Chicken, that formed a separate cluster from exotic male layer and exotic broiler chickens. The results also showed that the similarity level between exotic male layer and exotic broiler chickens was $94.65 \%$.
The analysis results of the phenotypic characteristics and similarity levels indicated that exotic broiler chickens had better phenotypic characteristics -for-meat type. Exotic broilers had been known as the type of chickens for meat having fast body growth. (Tamalludidi 2012) reported that exotic broiler chicken was usually ready to be harvested at the age of 35 days with a maximum body weight of 2$3 \mathrm{~kg}$. Chicken growth was believed to be influenced by genetic and nutritional and management factors (Tallentire et al. 2016; Neves et al. 2014). Tallentire et al. (2016) reported that a good genetic selection process followed by balanced nutrition in broiler chickens could provide efficient breeding process.

Results of this research also showed that exotic male layer chickens had quite strong similarity number of caharacteristics to exotic broiler chickens. Zaheer (2015) explained that domestication of modern chicken from members of the Gallus genus probably 8 thousand years ago in the Southern Asia. Exotic layer chicken was a type of modern chicken that was intended as laying hens and during this time exotic male layer chickens were not optimized. Currently in Indonesia it was being used as an alternative to exotic broilers due to its fairly good growth compared to local chickens. Exotic male layer chickens were recognized to reach $1.18 \mathrm{~kg}$ in 6 weeks (Daud et al. 2017).

Table 1. Analysis of morphometry of day old chick (DOC) of exotic broiler, kampung, exotic male layer, KUB-1 and Pelung chicken breeds

\begin{tabular}{lccccc}
\hline \hline Characteristic & Exotic broiler & Kampung & Exotic male layer & KUB-1 & Pelung \\
\hline Body weight, $(\mathrm{gr})$ & $41.32 \pm 1.04$ & $26.20 \pm 3.39$ & $38.36 \pm 1.86$ & $28.67 \pm 1.73$ & $35.58 \pm 3.47$ \\
Total height, $(\mathrm{cm})$ & $12.00 \pm 0.38$ & $7.50 \pm 0.47$ & $11.30 \pm 0.64$ & $10.33 \pm 0.43$ & $10.75 \pm 0.52$ \\
Body height, $(\mathrm{cm})$ & $8.56 \pm 0.49$ & $5.79 \pm 0.33$ & $8.26 \pm 0.35$ & $7.73 \pm 0.34$ & $8.42 \pm 0.66$ \\
Beak width, $(\mathrm{cm})$ & $1.03 \pm 0.21$ & $0.91 \pm 0.09$ & $1.31 \pm 0.11$ & $1.17 \pm 0.1 .16$ & $1.12 \pm 0.04$ \\
Beak length, $(\mathrm{cm})$ & $1.28 \pm 0.10$ & $1.19 \pm 0.13$ & $1.46 \pm 0.05$ & $1.28 \pm 0.08$ & $1.27 \pm 0.05$ \\
Head length, $(\mathrm{cm})$ & $4.14 \pm 0.31$ & $1.97 \pm 0.09$ & $3.99 \pm 0.11$ & $3.63 \pm 0.22$ & $3.62 \pm 0.28$ \\
Head width, $(\mathrm{cm})$ & $2.38 \pm 0.33$ & $1.69 \pm 0.23$ & $2.27 \pm 0.21$ & $1.87 \pm 0.13$ & $1.82 \pm 0.12$ \\
Body length, $(\mathrm{cm})$ & $8.31 \pm 0.37$ & $4.32 \pm 0.30$ & $8.92 \pm 0.24$ & $7.92 \pm 0.29$ & $9.23 \pm 0.59$ \\
Body width, $(\mathrm{cm})$ & $4.50 \pm 0.38$ & $4.08 \pm 0.37$ & $4.27 \pm 0.25$ & $3.80 \pm 0.18$ & $4.23 \pm 0.23$ \\
Chest circumference, $(\mathrm{cm})$ & $10.88 \pm 0.83$ & $7.55 \pm 0.54$ & $10.58 \pm 0.44$ & $10.00 \pm 0.40$ & $10.94 \pm 0.75$ \\
Wing length, $(\mathrm{cm})$ & $5.44 \pm 0.39$ & $4.05 \pm 0.18$ & $4.51 \pm 0.20$ & $3.78 \pm 0.37$ & $4.86 \pm 0.35$ \\
Neck length, $(\mathrm{cm})$ & $2.44 \pm 0.49$ & $2.31 \pm 0.44$ & $2.47 \pm 0.14$ & $2.55 \pm 0.26$ & $3.43 \pm 0.79$ \\
Thigh length, $(\mathrm{cm})$ & $3.86 \pm 0.23$ & $3.17 \pm 0.23$ & $3.86 \pm 0.14$ & $3.73 \pm 0.30$ & $3.59 \pm 0.16$ \\
Calves length, $(\mathrm{cm})$ & $3.83 \pm 0.26$ & $3.31 \pm 0.22$ & $3.67 \pm 0.25$ & $3.69 \pm 0.19$ & $3.86 \pm 0.32$ \\
Tibia tarsus, $(\mathrm{cm})$ & $4.95 \pm 0.31$ & $4.32 \pm 0.17$ & $4.87 \pm 0.14$ & $4.71 \pm 0.23$ & $4.91 \pm 0.18$ \\
\hline
\end{tabular}




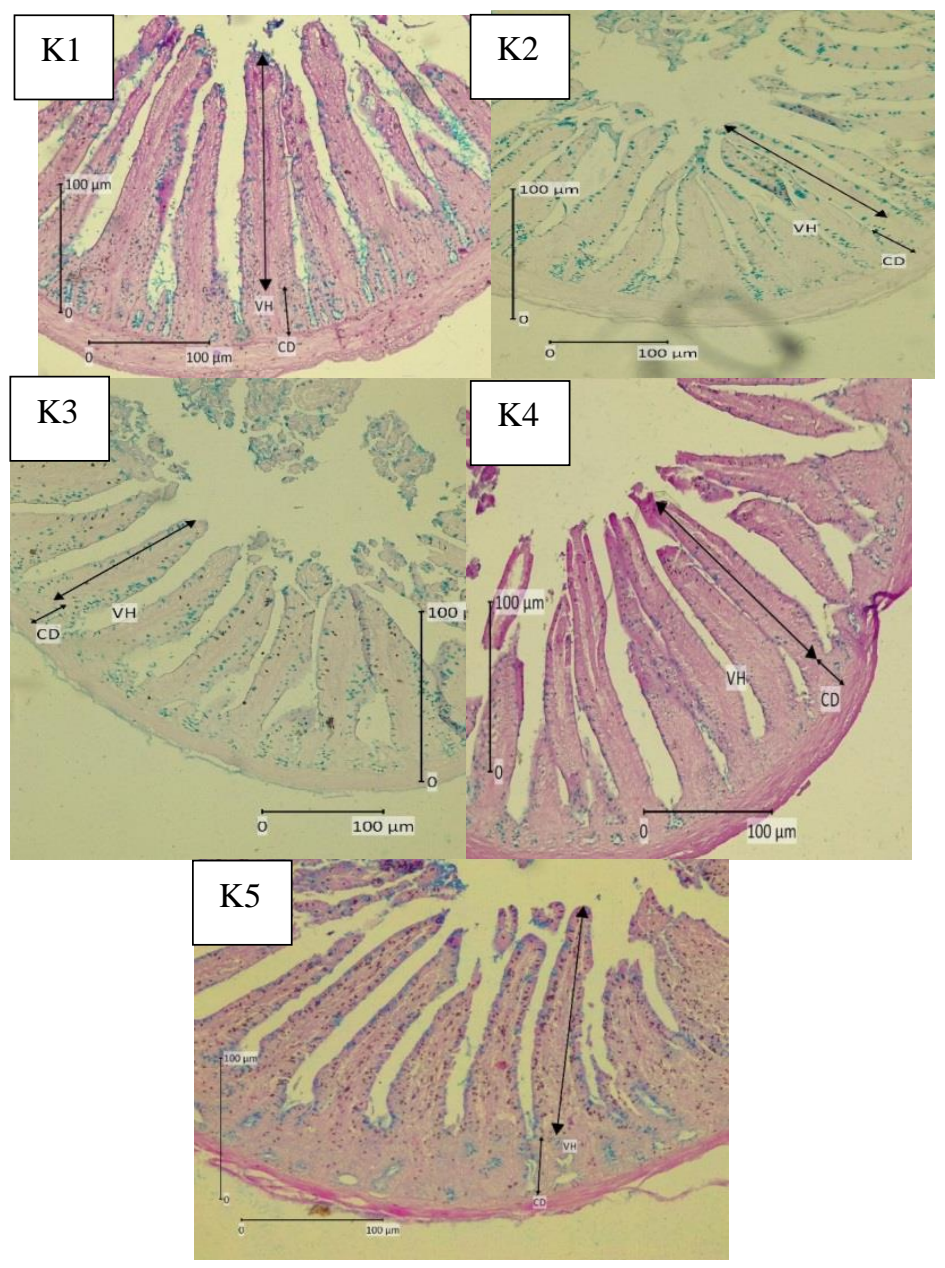

Figure 1. Duodenum morphology of DOC with 10x10 magnification and PAS stain. VH: Villus Height. CD: Crypte Depth.K1: Exotic broiler chicks; K2: Kampung chicks; K3: Exotic male layer chicks; K4: KUB-1 chicks. K5: Pelung chicks.

The current research also looks at the similarity values of Pelung, Kampung and KUB-1 chickens which were the types of chicken developed by IRIAP. KUB-1 chicken was the result of selection of kampung chickens. According to Sartika et al. (2013), KUB-1 chicken were black feather color, striated color, columbian type, and white feather color. The adult male body weight ranges from $1.3-1.6 \mathrm{~kg}$ while in females it ranges from 1.2-1.4 kg at peak production. Kampung chickens had slow growth and little egg production capabilities. Kampung chickens could achieve optimal growth of around 1.2-1.5 kg (Nataamijaya 2010). Pelung chicken is a native Indonesian chicken that has been developed in Cianjur area, West Java, Indonesia. Nataamijaya (2010) reported that pelung chickens, besides having superiority in crowing, it could also be used as broiler type of chicken. Pelung chicken in 90 days old had ability to reach body weight of 1.1-1.3 $\mathrm{kg}$ (Iskandar \& Susanti 2007).

This research also reported body morphometric values, visceral organ weight and small intestinal histo-morphology among all types of chickens observed. Results showed that morphometric values, visceral organ weight and small intestinal morphology of exotic broiler DOC were still better than DOC group of other types of chicken. This result is in line with the research conducted by Kokoszyński et al. (2017) which explains that broilers have superior body conformation to support growth. The advantage of morphometric measurement method is that morphometry provides a description of quantitative elements. Morphometric data analysis could find out the part where the important changes occur as the references for the research to be (Zelditch et al. 2004). Some of the most important quantitative characteristics in bird morphometry were body weight, femur length, tarsometatarsus, circumference of tarsometatarsus, third finger length and wings (Kurniawan \& Arifianto 2017).

Visceral organs of chickens such as the heart, liver and digestive system are important parts of metabolic process of the body. The heart organ has the ability to circulate blood to the lungs in the exchanging process of $\mathrm{O}_{2}$ and $\mathrm{CO}_{2}$ to help the metabolic process of the body. The liver organ functions to secrete bile to be channeled to the duodenum. Bile can neutralize 
Table 2. Analysis visceral organ DOC of exotic broiler, kampung, exotic male layer, KUB-1 and Pelung chicken breeds

\begin{tabular}{lccccc}
\hline \hline Visceral organ & Exotic broiler & Kampung & Exotic male layer & KUB-1 & Pelung \\
\hline Liver, (gr) & $1.54 \pm 0.13$ & $1.15 \pm 0.33$ & $1.12 \pm 0.07$ & $0.94 \pm 0.09$ & $1.29 \pm 0.05$ \\
Heart, (gr) & $0.44 \pm 0.05$ & $0.26 \pm 0.04$ & $0.33 \pm 0.05$ & $0.25 \pm 0.03$ & $0.25 \pm 0.02$ \\
Ventriculus, (gr) & $0.48 \pm 0.04$ & $0.33 \pm 0.07$ & $0.45 \pm 0.03$ & $0.31 \pm 0.03$ & $0.48 \pm 0.03$ \\
Proventriculus, (gr) & $3.06 \pm 0.33$ & $2.25 \pm 0.39$ & $3.03 \pm 0.15$ & $1.85 \pm 0.22$ & $2.81 \pm 0.24$ \\
Small intestine length, (cm) & $43.49 \pm 2.73$ & $33.37 \pm 3.85$ & $45.06 \pm 3.43$ & $33.83 \pm 2.41$ & $57.38 \pm 2.49$ \\
Small intestine weight, (gr) & $1.78 \pm 0.09$ & $1.13 \pm 0.21$ & $1.64 \pm 0.07$ & $0.84 \pm 0.09$ & $2.95 \pm 0.45$ \\
Bursa fabricius weight, $(\mathrm{gr})$ & $0.064 \pm 0.02$ & $0.043 \pm 0.02$ & $0.063 \pm 0.02$ & $0.044 \pm 0.01$ & $0.09 \pm 0.05$ \\
$1 / 2$ Pectoralis muscle weight, $(\mathrm{gr})$ & $0.96 \pm 0.08$ & $0.47 \pm 0.07$ & $0.83 \pm 0.06$ & $0.66 \pm 0.08$ & $1.07 \pm 0.03$ \\
$1 / 2$ Pectoralis muscle area, $\left(\mathrm{cm}^{2}\right)$ & $4.97 \pm 0.33$ & $3.29 \pm 0.29$ & $4.12 \pm 0.44$ & $3.80 \pm 0.32$ & $5.86 \pm 0.20$ \\
\hline
\end{tabular}

Table 3. Analysis of villus height, crypte depth, villus/crypte ratio, number of Goblet cells and area of Goblet cell DOC of exotic broiler, kampung, exotic male layer, KUB-1 and Pelung chicken breeds

\begin{tabular}{|c|c|c|c|c|c|}
\hline Variable & \multirow{2}{*}{ Exotic broiler } & \multirow{2}{*}{ Kampung } & \multirow{2}{*}{ Exotic male layer } & \multirow{2}{*}{ KUB-1 } & \multirow{2}{*}{ Pelung } \\
\hline Duodenum & & & & & \\
\hline Villus height, $(\mu \mathrm{m})$ & $191.32 \pm 9.98$ & $142.12 \pm 6.87$ & $178.67 \pm 6.75$ & $161.92 \pm 8.66$ & $235.63 \pm 5.19$ \\
\hline Crypte depth, $(\mu \mathrm{m})$ & $45.94 \pm 3.54$ & $32.97 \pm 2.62$ & $31.99 \pm 1.79$ & $37.43 \pm 2.38$ & $46.04 \pm 7.61$ \\
\hline V/Cratio & $4.12 \pm 0.27$ & $4.51 \pm 0.35$ & $5.59 \pm 0.29$ & $4.34 \pm 0.29$ & $5.22 \pm 0.80$ \\
\hline Number of Goblet cells/ 100 & $30.20 \pm 1.48$ & $29.00 \pm 1.22$ & $30.60 \pm 2.30$ & $25.60 \pm 5.59$ & $26.5 \pm 1.91$ \\
\hline Area of Goblet cell, $\left(\mu \mathrm{m}^{2}\right)$ & $10.50 \pm 1.02$ & $7.81 \pm 1.06$ & $9.32 \pm 1.16$ & $5.96 \pm 0.59$ & $9.65 \pm 1.35$ \\
\hline \multicolumn{6}{|l|}{ Jenjunum } \\
\hline Villus height, $(\mu \mathrm{m})$ & $144.92 \pm 5.05$ & $126.3 \pm 6.07$ & $124.99 \pm 7.81$ & $78.78 \pm 3.46$ & $138.54 \pm 2.66$ \\
\hline Crypte depth, $(\mu \mathrm{m})$ & $30.89 \pm 2.56$ & $25.46 \pm 3.01$ & $27.61 \pm 1.04$ & $19.24 \pm 1.53$ & $40.89 \pm 2.36$ \\
\hline V/Cratio & $4.72 \pm 0.47$ & $5.02 \pm 0.49$ & $4.53 \pm 0.31$ & $4.11 \pm 0.31$ & $3.39 \pm 0.23$ \\
\hline Number of Goblet cells/ 100 & $34.20 \pm 3.42$ & $43.00 \pm 7.48$ & $38.20 \pm 5.17$ & $31.20 \pm 4.15$ & $32.40 \pm 5.46$ \\
\hline Area of Goblet cell, $\left(\mu \mathrm{m}^{2}\right)$ & $8.98 \pm 1.32$ & $7.53 \pm 1.27$ & $8.67 \pm 0.61$ & $4.89 \pm 0.54$ & $8.13 \pm 1.49$ \\
\hline \multicolumn{6}{|l|}{ Ileum } \\
\hline Villus height, $(\mu \mathrm{m})$ & $125.93 \pm 4.15$ & $95.40 \pm 7.49$ & $138.01 \pm 6.75$ & $102.02 \pm 9.42$ & $137.73 \pm 7.69$ \\
\hline Crypte depth, $(\mu \mathrm{m})$ & $34.33 \pm 5.44$ & $27.47 \pm 1.25$ & $27.47 \pm 1.25$ & $23.55 \pm 1.41$ & $38.59 \pm 6.77$ \\
\hline V/Cratio & $3.68 \pm 0.24$ & $3.8 \pm 0.75$ & $5.04 \pm 0.43$ & $4.33 \pm 0.26$ & $3.63 \pm 0.49$ \\
\hline Number of Goblet cells/ 100 & $30.20 \pm 2.68$ & $24.60 \pm 2.30$ & $29.60 \pm 4.22$ & $28.80 \pm 1.79$ & $37.20 \pm 2.77$ \\
\hline Area of Goblet cell, $\left(\mu \mathrm{m}^{2}\right)$ & $13.14 \pm 1.75$ & $10.60 \pm 0.80$ & $11.27 \pm 1.46$ & $10.04 \pm 0.76$ & $13.29 \pm 0.94$ \\
\hline
\end{tabular}

stomach acid and form an emulsion in the stomach. Both functions help absorption and translocation of fatty acids during the absorption of feed essence (Swatson et al. 2003). (Kokoszyński et al. 2017) reported that broilers are known to have the ability in weight growth which is supported by the balance of its visceral organs.

The digestive part in the chicken's body is an important part in the absorption process of nutrients. The small intestine consisting of the duodenum, jejunum and ileum is the essential part for such process. The small intestinal morphology such as villous height, crypt depth and number of goblet cells plays an important role in increasing the absorption ability, preventing the occurrence of inflammation and preparing for the regeneration of epithelial cell (Rajput et al. 2013; Uni et al. 2003; Deplancke \& Gaskins 2001). Broilers are known to have good small intestinal morphology for the process of absorption in the intestine and in line with the growth of body weight (Ibrahim 2008). 


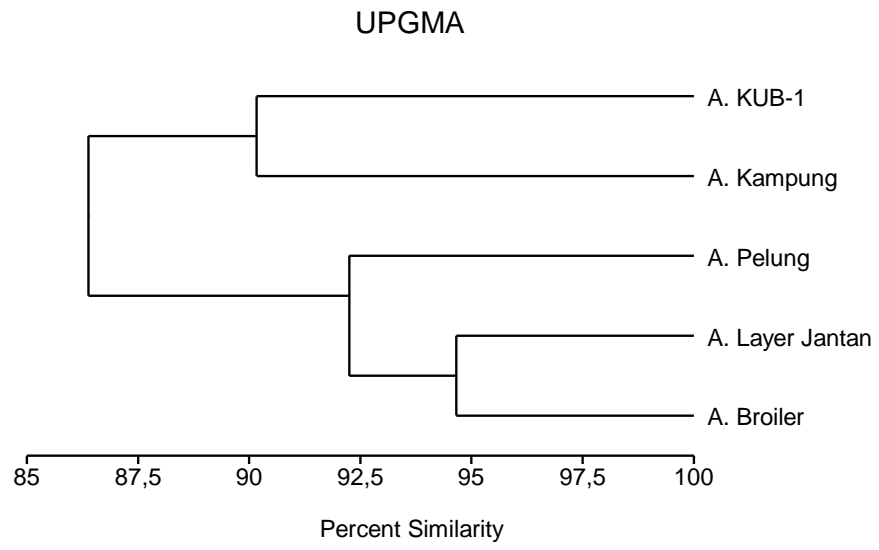

Figure 2. Percentage similarity of dendogram morphometry, visceral organ and small intestine morphology on day old chick (DOC) of exotic broiler, kampung, exotic male layer, KUB-1 and Pelung chicken breeds using UPGMA methods.

\section{CONCLUSION}

The similarity level of pelung chicken as Indonesian local chicken was quite close to the type of exotic broiler and exotic male layer chicken so it was promising as an alternative for meat type of local chicken.

\section{REFERENCES}

Daud M, Fuadi Z, Mulyadi M. 2017. Performan dan persentase karkas ayam ras petelur jantan pada kepadatan kandang yang berbeda. J Agripet. 17:67.

Deplancke B, Gaskins HR. 2001. Microbial modulation of innate defense: goblet cells and the intestinal mucus layer. Am J Clin Nutr. 73:1131S-1141S.

Ibrahim S. 2008. Hubungan ukuran-ukuran usus halus dengan berat badan broiler. J Agripet. 8:42.

Iskandar S. 2018. Phenotypic characterization and distribution of Sensi-1 Agrinak chicken. Wartazoa. 28:51-60.

Iskandar S, Susanti T. 2007. Karakter dan manfaat ayam pelung di Indonesia. Wartazoa. 17:128-136.

Kokoszyński D, Bernacki Z, Saleh M, Stęczny K, Binkowska M. 2017. Body conformation and internal organs characteristics of different commercial broiler lines. Rev Bras Ciência Avícola. 19:47-52.

Kurniawan N, Arifianto A. 2017. Ornitologi: Sejarah, biologi dan konservasi. Malang (Indones): UB Press.

Nataamijaya AG. 2000. The native chickens of Indonesia. Bul Plasma Nutfah. 6:1-6.

Nataamijaya AG. 2010. Pengembangan potensi ayam lokal untuk menunjang peningkatan kesejahteraan petani. J Penelitian Pengembangan. 29:131-138.

Neves D, Banhazi T, Nääs I. 2014. Feeding behaviour of broiler chickens: a review on the biomechanical characteristics. Rev Bras Ciência Avícola. 16:01-16.
Rajput N, Muhammad N, Yan R, Zhong X, Wang T. 2013. Effect of dietary supplementation of curcumin on growth performance, intestinal morphology and nutrients utilization of broiler chicks. J Poult Sci. 50:4452.

Sartika T, Desmayanti, Iskandar S, Resnawati H. 2013. Ayam KUB-1. Jakarta (Indones): IAARD Press.

Setiawan H, Jingga ME, Saragih HT. 2018. The effect of cashew leaf extract on small intestine morphology and growth performance of Jawa Super chicken. Vet World. 11:1047-1054.

Swatson HK, Iji PA, Gous RM. 2003. Body growth, visceral organ weight and intestinal digestive enzyme fchickens on diets varying in energy and protein contents. J Anim Vet Adv. 2:305-311.

Tallentire CW, Leinonen I, Kyriazakis I. 2016. Breeding for efficiency in the broiler chicken: A review. Agron Sustain Dev. 36:66.

Tamalludidi F. 2012. Ayam broiler, 22 hari panen lebih untung. Jakarta (Indones): Penebar Swadaya.

Uni Z, Smirnov A, Sklan D. 2003. Pre- and posthatch development of goblet cells in the broiler small intestine: effect of delayed access to feed. Poult Sci. 82:320-327.

Zaheer K. 2015. An updated review on chicken eggs: production, consumption, management aspects and nutritional benefits to human health. Food Nutr Sci. 06:1208-1220.

Zelditch ML, Swiderski DL, Sheetsy HD, Fink WL. 2004. Geometric morphometrics for biologists: A primer. Rio de Janeiro (Braz): Elsevier Ltd. 